\title{
THE EFFECTIVENESS OF REGIONAL REGULATION ENFORCEMENT RELATED TO THE MANAGEMENT OF COVID-19 IN STREET SELLERS IN JAKARTA BARAT
}

\author{
Bayquni* \\ Faculty of Communication Science, Universitas Prof. Dr. Moestopo (Beragama) \\ *Correspondence: bayquni_bayu@dsn.moestopo.ac.id
}

\begin{abstract}
ARTICLE INFO
Article History:

received: $28 / 09 / 2020$

revised: 09/12/2020

accepted: 13/02/2021

Keywords:

Effectiveness; Enforcement of Regional Regulation on Covid19; Civil Police Unit; Street Sellers

DOI:

ABSTRACT

Enforcement of local regulations regarding the handling of Covid 19 against street vendors in the West Jakarta Administrative City is still ineffective based on the lack of discipline on street vendors to comply with Health Protocols and the efforts of Satpol PP in enforcing PERDA to overcome Covid 19. While the theory used is effectiveness according to Tyson \& Jackson, which consists of 1) Briefing, (2) Delegation, (3) Control, (4) Accountability, (5) Efficiency, (6) Coordination, (7) Adaptation, (8) Social Systems and Individual Expectations. The research method in this research uses qualitative methods. A qualitative approach is used because it involves the formulation of symptoms, information, or information regarding the enforcement of local regulations on Covid-19 prevention by Satpol PP against street vendors in West Jakarta Administrative City. The use of qualitative methods is supported by a project map on the Nvivo 12 application. The research findings show that the implementation of the enforcement of the Covid-19 countermeasures PERDA on street vendors in West Jakarta City Administration by Sat Pol PP, namely: (1) Satpol PP in enforcing the Covid 19 countermeasures PERDA in street vendors is still not fully effective in the implementation of delegation and control, accountability, efficiency, coordination and adaptation; and (2) The concept of improvement that can be carried out is the enforcement of the regulation on Covid 19 prevention by implementing humanist normative pattern of street vendor control, namely performance management of street vendors with environmental control, social services and economic empowerment of street vendors as business actors in the economic system. community organized according to the conditions of the Covid pandemic 19
\end{abstract}

\section{INTRODUCTION}

During the Covid-19 pandemic, the urban informal sector was under tremendous pressure. According to Chen (2020), during the Covid-19 pandemic, the informal sector in urban areas faced the threat of violence from the authorities, including moving work locations. This increases discrimination and creates a stigma that the informal sector such as street vendors is the source of the spread of the virus. Song (2020) and Honey-Rosés et. al (2020) during the Covid-19 pandemic there was a dilemma in informal economic arrangements in public spaces such as street vendors. The challenges faced are not much 
different from the era before Covid-19. According to Song (2020), there are two dilemmas that must be understood in dealing with the informal sector such as street vendors during the pandemic. The first dilemma is to strike a balance between road management and the mobility of street vendors and the second dilemma is to encourage street vendors to comply with health regulations.

On the other hand, Honey-Rosés et. al (2020) views that the regulation of the informal sector, especially in the public sphere during the pandemic period, faces similar issues to the conditions before the pandemic, where it is almost impossible to tightly regulate or improve the informal sector which tends to be vulnerable.

The difficulty of regulating the informal sector in urban public spaces, including street vendors in various big cities in the world, has been stated by Chen (2020), Song (2020) and Honey-Rosés et. al (2020) also occurred in Indonesia, especially in the capital city of Jakarta.

The responsibility for providing health protection for the public from the spread of the Covid-19 pandemic is carried out by the Regional Government as outlined in Regional Regulation Number 2 of 2020 concerning Covid-19 Handling. This regional regulation (Perda) explicitly regulates the implementation of the obligation to protect public health, including for street vendors. The results of preliminary observations show that the implementation or enforcement of Perda No.2 of 2020 for the informal sector, especially street vendors in DKI Jakarta, is still not optimal and faces a variety of difficult challenges.

The enforcement of Perda No.2 of 2020 has not been maximally enforced, especially by the relevant regional apparatus, namely the Satpol PP, which describes the dynamics that occur in the field and describes the phenomenon of the organizational capacity of regional apparatus in achieving goals. This is as expressed by Federman in Ashraf (2012) explaining "The ability of an organization to access and absorb resources and consequently achieve its aims". Ideally, the Satpol PP organizational apparatus should have the ability to use resources to achieve goals in order to achieve this goal. enforcement of local regulations related to Covid-19 Countermeasures. This is as stated by McCann (2004) that "Criterion of the organization's successful fulfillment of their purposes through core strategies. The success of the organization is due to the achievement of goals through predetermined strategies.

Based on the description above, this journal aims to deepen the extent to which the effectiveness of the enforcement of regional regulations on Covid 19 response to street vendors, especially in urban areas such as Jakarta. In addition, this journal also aims to build an effective model so that it can be a reference for local governments in order to solve or at least minimize the various problems that occur.

\section{Conceptual Framework}

In carrying out the function of enforcing local regulations, Regional Governments in Indonesia are equipped with regional apparatuses known as the Civil Service Police Unit or Satpol PP. Satpol PP is one of the regional apparatus organizations that has the task of maintaining and implementing public order and order as well as enforcing regional regulations and governor / regent / mayor regulations. To carry out these tasks, Satpol PP has functions, among others, to implement public order and peace as well as uphold regional regulations and governor regulations; coordinating the maintenance and administration of public order and order as well as enforcing regional regulations and governor regulations with state police officers, Civil Servant Investigators (PPNS) and / or other apparatus; supervision of the community in order to comply with and comply with regional regulations and governor regulations.

With such descriptions of institutional duties and functions, the implementation of 
Regional Regulation Number 2 of 2020 concerning Covid-19 Handling is the task and function of Satpol PP in enforcing it. The effectiveness of the implementation of Satpol PP's duties and functions in enforcing Perda No. 2 of 2020 on street vendors certainly has a broad impact on the implementation of public order and order which is another main task of Satpol PP. The effectiveness of the implementation of Satpol PP's duties and functions appears to be a phenomenon of the organizational behavior of the regional apparatus during the Covid-19 pandemic, which indicates and represents certain conditions and characteristics in the management of public administration in the regions when the situation is not normal.

Article 10 letter $\mathrm{f}$ of Perda No. 2 of 2020 explicitly regulates that public health protection is carried out in public places and facilities which include street vendors or snack stalls. Article 16 paragraph 1 of the same Perda also stipulates that street vendors know hawker stalls in fostered locations, temporary locations, and certain other locations are obliged to carry out public health protection, which includes implementing education and Covid-19 prevention protocols; and restrictions on physical interaction between visitors.

In article 16 paragraph 2 of Perda No. 2 of 2020, it is stipulated that street vendors / hawker stalls at fostered locations, temporary locations and certain other locations that do not carry out public health protection obligations will be subject to administrative sanctions in the form of a written warning and dissolution of activities. Furthermore, Article 16 paragraph 3 of the same Perda stipulates that the imposition of administrative sanctions on street vendors in certain other places outside the fostered locations and temporary locations is carried out by Satpol PP.

Regarding this phenomenon, an interesting quesion to be answered conceptually and factually is "How is the effectiveness of Satpol PP in enforcing regional regulations on Covid 19 countermeasures against street vendors?"

Related to the issue of organizational effectiveness, it can be understood in more depth by using the Tyson \& Jackson (2000) approach which states that the organizational effectiveness criteria include direction, delegation, control, accountability, efficiency, coordination, adaptation, social systems and individual expectations. The dimensions presented by Tyson \& Jackson (2000) serve as the right analysis knife to assess the effectiveness of the implementation of the said Regional Regulations.

Based on the effectiveness theory from Tyson \& Jackson (2000), a conceptual definition was prepared that the effectiveness of Satpol PP in enforcing local regulations against street vendors is the success of Satpol PP in curbing the existence of street vendors in West Jakarta Administrative City which is reviewed according to Direction, Delegation, Control, Accountability, Efficiency, Coordination, Adaptation, Social systems and individual expectations. From the conceptual definition, 8 dimensions of analysis are derived: (1) Dimensions of Direction, (2) Dimensions of Delegation, (3) Dimensions of Control, (4) Dimensions of Accountability, (5) Dimensions of Efficiency, (6) Dimensions of Coordination, (7) Dimensions of Adaptation, (8) Dimensions of the social system and individual expectations.

\section{METHOD}

This research uses a qualitative research approach. The qualitative approach is used because it involves the formulation of symptoms, information, or information regarding the enforcement of local regulations on the handling of Covid-19 by Satpol PP against street vendors in urban areas. The use of qualitative methods is supported by a project map on the Nvivo 12 application.

The locus which is the object of research is the Administrative City of West Jakarta which has the characteristics of a 
metropolitan urban population with street vendors scattered throughout the city. 21 research informants were determined using the snow ball technique. Secondary data collection from various books and documents using literature study; Primary data collection from pre-research informants using interview and observation techniques. The data analysis used descriptive analysis which was developed with triangulation analysis by observers.

\section{RESULT AND DISCUSSION}

\section{Effectiveness of Enforcement of Regional Regulations Related to Covid-19 Handling on Street Sellers}

The results of interviews with research informants and discussions were arranged according to the construct of Tyson \& Jackson's organizational effectiveness theory which includes eight dimensions of analysis. The discussion is directed to get the practical implications of each of the dimensions of the analysis. The results of the discussion of each of the dimensions of the analysis are as follows:

\section{Direction Dimension}

If analyzed, in the enforcement of the intended regional regulations, the dimensions of operational direction given by the leadership to Sat Pol PP are based on the description of the duties and functions of Sat Pol PP in the implementation of regional government and are directed by the SOP (Standard Operating Procedure) of Sat Pol PP which is normative juridical in nature. However, the implementation of these operational directives is faced with conditional and situational obstacles that arise from human rights issues inherent in street vendors and the awareness of Sat Pol PP members to be humane towards street vendors. With these constraints and obstacles, the effectiveness of the implementation of Sat Pol PP's duties and functions in enforcing the Perda is not optimal. Therefore, it is necessary to align the concept of understanding normative juridical directives with the concept of humanist directives so that Sat Pol PP members are accustomed to normative humanist task behavior. This means that implementing regulations on controlling street vendors needs to be carried out with a friendly approach, which does not commit violence and confiscation of goods.

\section{Delegation Dimension}

From the descriptive analysis, it is illustrated that the dimensions of Satpol PP Operational Delegation issued in the context of enforcing regional regulations apply according to the organizational structure of Sat Pol PP from the Provincial level to the Kelurahan level. Sat Pol PP's delegation of authority in implementing policies and controlling activities of street vendors in the West Jakarta Administrative City is not only highly hierarchical but also highly procedural. The implementation of operational control is faced with conditional constraints related to the economic needs of street vendors and situational obstacles that arise from social problems of street vendors. With the view that it is justified to exercise an authority that is forced to violate human rights because in certain situations it is the only way to deal with a situation, making it difficult for Sat Pol PP to carry out public service functions optimally to support the realization of Jakarta free from the Covid Pandemic 19 .. With constraints and obstacles as well as such difficulties that the effectiveness of the implementation of Sat Pol PP's duties and functions in enforcing regional regulations is not optimal. Therefore, a more decentralized pattern of delegation of authority is needed so that the Sat Pol PP can carry out their public service functions optimally. This means that a more practical and decentralized pattern of delegation of authority is needed so that the Sat Pol PP can perform public service functions optimally to support the realization of a Social Friendly City Jakarta.

\section{Control Dimension}

From the descriptive analysis, it can be seen that the Satpol PP Operational Control 
in enforcing regional regulations applies according to the organizational pattern of Sat Pol PP. The operational control of Sat Pol PP in implementing policies and controlling activities of street vendors in West Jakarta Administrative City is faced with internal and external technical obstacles related to the weak implementation of the coordination function, and conditional obstacles that stem from the social and economic problems of street vendors. With the pattern of controlling street vendors that are not always based on surveys, often carried out suddenly, faced with challenges of providing solutions to street vendors, and cooperation with street vendors is needed, Sat Pol PP is difficult to carry out the operational control function of controlling street vendors optimally in carrying out regional regulation enforcement activities.

With such patterns and obstacles, the effectiveness of the implementation of Sat Pol PP's duties and functions in enforcing regional regulations and regional head regulations is not conceptual. Therefore, a more conceptional control pattern of street vendor control is needed by developing functional cooperation with agencies and institutions that are concerned with social services and economic empowerment of street vendors. This means that the conceptual operational control of street vendors requires the development of functional cooperation between Sat Pol PP and agencies and institutions that are concerned with social services and economic empowerment of street vendors.

\section{Responsibility Dimension}

From the descriptive analysis, it is illustrated that in terms of the operational responsibility dimensions of Sat Pol PP in enforcing regional regulations, there is a performance accountability that applies according to the function of the position and the scope of the activities carried out. The operational responsibility of Sat Pol PP in implementing policies and control activities of street vendors in West Jakarta Administrative City is limited to the scope of structural performance accountability according to legal provisions governing the accountability of the performance of the government bureaucracy. Given the fact that what is done by Sat Pol PP takes place in front of the public and is related to the public interest, and Sat Pol PP uses public funds originating from the APBD; then the performance accountability of Sat Pol PP is not limited to performance accountability alone. The performance accountability of Sat Pol PP in implementing various policies and enforcement activities includes social accountability which refers to the role of NGOs and the function of the mass media as well as political accountability which refers to the function of the legislative body. However, Sat Pol PP is not used to social accountability and political accountability.

Thus, the effectiveness of the implementation of Sat Pol PP's duties and functions in enforcing regional regulations and regional head regulations is not transparent and is limited only according to the structural interests of the bureaucracy. Therefore, a transparent operational accountability pattern for controlling street vendors is needed in accordance with the principles of public accountability. This public accountability needs to be demonstrated by the Sat Pol PP at the end of the operation of controlling the street vendors, among others by holding a press conference to explain the reasons for controlling and following up on controlling the street vendors. This means that the operational responsibility for controlling street vendors by Sat Pol PP needs to be expanded by enforcing public accountability in accordance with the principles of good governance.

\section{Efficiency Dimension}

From the operational efficiency dimension of Sat Pol PP, it is illustrated that the enforcement of regional regulations is a process of maximizing the function of limited administrative resources. On the other hand, SatPol PP is not a producing agency such as the Revenue Service or other 
producing agencies. Therefore, the measure of efficiency in the implementation of Sat Pol PP duties and functions is not the added value or budget savings; but on maximizing the budget function measured according to the effectiveness of the implementation of activities. This means that in the dimensions of the implementation of duties and functions, it is possible to use large budget allocations outside of the previously determined budget plan, because Sat Pol PP has to overcome very urgent order issues. In this dimension, the efficiency parameter in the perspective of the Sat Pol PP performance in curbing street vendors can be turned into a parameter of effectiveness, namely how the goals and objectives of implementing the duties and functions of controlling the street vendors are achieved. Therefore, Sa Pol PP must be good at managing organizational performance with limited budget allocation support. This means that the operational efficiency of controlling street vendors by Sat Pol PP is an effort to maximize the function of limited budget allocations so that the implementation of various policies and activities to control street vendors is effective.

\section{Coordination Dimension}

In terms of coordination, Sat Pol PP in enforcing regional regulations is a process of harmonizing and balancing the performance of administrative resources for controlling street vendors. The coordination of resource performance includes human resource performance, budget performance, policy performance and facility performance, including information technology performance. The implementation of the coordination function in controlling street vendors is mostly carried out to meet the technical operational and structural needs of the Sat Pol PP work units and between Sat Pol PP and related agencies / institutions. However, the implementation of the coordination function to meet social needs related to the existence of street vendors is not much done. Therefore, the implementation of various policies and activities to control street vendors does not cover all the dimensions of the problem, especially the dimensions of the problems that cause the handling of street vendors to be not optimal. This means that the operational coordination of PKL control carried out by Sat Pol PP is not optimal because it has not touched all parties with an interest in the presence of PKL as one of the informal business actors who have a certain potential and position in the economic system of the Jakarta community.

\section{Adaptation Dimension}

In terms of adaptation, Sat Pol PP in enforcing local regulations is the technical adjustment of street vendors controlling operations that arise from formal legality demands and challenges to make Jakarta City free from the Covid 19 pandemic which is socially just. This operational technical adaptation has been carried out by the DKI Jakarta Regional Government but has not been optimal in fulfilling the demands of formal legality and the challenges of realizing a Jakarta City free from the Covid 19 pandemic and Social Justice. Therefore, the implementation of various PKL control policies and activities is not optimal in responding to, overcoming and anticipating all dimensions of PKL problems. This means that the operational technical adaptation of PKL control carried out by Sat Pol PP is not optimal in responding, overcoming and anticipating all dimensions of PKL problems to support the realization of a Jakarta City Free from the Covid 19 pandemic and Social Justice.

\section{Dimension of the Social System and Individual Expectations}

In terms of the social system and individual expectations, the social system and individual expectations that formally arise through the operational activities of the Sat Pol PP in enforcing regional regulations are the social systems and individual expectations that are built based on the philosophy of Pancasila and the 1945 
Constitution. However, the social system and expectations These individuals in implementing various policies and controlling the Sat Pol PP are still limited to the social system and individual expectations in the internal environment of the Sat Pol PP. The social system and individual expectations in the broadest sense, especially the social system and individual expectations related to street vendors, have not been optimally actualized. Therefore, the implementation of various policies and PKL control activities is not optimal in supporting the realization of a Jakarta City free from the Covid 19 Pandemic and Social Justice. This means that the social system and individual expectations that formally emerge through the operational activities of the Sat Pol PP in enforcing regional regulations have not been optimal to support the realization of Jakarta, a Covid 19 Pandemic Free City and Justice.

From the description of the problem above, it is clear that there are many problems that arise from the application of the DKI Jakarta Provincial Regulation Number 2 of 2020 concerning Covid 19 Handling, in order to make Jakarta free from the Covid 19 Pandemic and Social Justice, so inevitably the DKI Jakarta Provincial Government must Adjusted the Covid 19 Perda and with the adjustment of the Covid 19 Perda also made operational technical adjustments to the Sat Pol PP in curbing street vendors. The operational technical adjustments of Sat Pol PP are carried out, among others, by compiling a humanist normative pattern for controlling street vendors, which includes environmental control, social services and economic empowerment of street vendors as one of the business actors in the community economic system which is implemented in the context of realizing Friendly Cities. Social and Social Justice.

\section{Ideal Concept in Enforcement of Regional Regulations Handling Covid 19 on Street Traders}

Referring to the phenomenon of enforcement of Regional Regulations related to the handling of Covid 19 on street vendors in the West Jakarta Administrative City as explained above, the author tries to describe several new conceptual ideas that are constructed according to the definitions stated as follows:

1. Environmental Control: Environmental control is the regulation and arrangement of public facilities, social facilities and certain places in the areas of terminals, ports, airports, business activity centers, tourist zones and so on in order to create and maintain an orderly, safe, environmental system. clean, and beautiful for people to do transactions, social activities, and social interactions. The reality shows that public facilities, social facilities and certain places tend to be used as business premises by street vendors (PKL) who consist of several types of merchandise. Because transactions, social activities, and social interactions between community members and street vendors are one of the manifestations of human rights in fulfilling the daily needs of life and expression, then controlling street vendors in the environment should be carried out with a friendly approach, not violent and not confiscating goods belonging to street vendors; and also do not impose certain fines on citizens who carry out transactions, social activities, and social interactions. Such an approach should be carried out by officers with firm, consistent and consistent duty behavior. Promotion, communication and direct dialogue with street vendors until a certain agreement is reached is an ideal first step in implementing the Humanist Normative Patterned PKL Control Policy. The implementation of public policies like this is very important to support the realization of a city free from the Covid 19 epidemic and Social Justice. For that, environmental control 
needs to be followed by an evaluation of the performance of control. Based on the results of the evaluation, PKL who have experienced certain impacts that require special attention, especially PKL who come from outside the region, are given integrated social services to various related parties.

2. Social Service: Social service is a type of public service which is the obligation of state administrators and is the right of every citizen. These social services are carried out by government agencies and institutions to street vendors in order to respond to, overcome and / or anticipate social risks that arise as a result of implementing policies and operational activities to control street vendors. The social services are carried out by government agencies and institutions that are concerned with and related to social welfare efforts by providing counseling, guidance and social assistance to street vendors who are affected by the law enforcement. Social services are carried out by conducting Problem Perspective Analysis (APM) for street vendors who need special attention, and are deemed necessary to be assisted in finding solutions to the social risks they face. APM approach includes Problem Background Analysis; Fact Problem Analysis; Problem Impact Analysis; Meta Problem Analysis; Fisolophy Analysis of the Problem; and Problem Solution Analysis to determine social service follow-up.

3. Economic Empowerment: Economic empowerment is the provision of business skills, strengthening financial capital and / or development of economically productive street vendors which are organized in a patterned, directed and integrated manner by government agencies and institutions that are concerned with and related to the development of Medium, Small and Micro Enterprises. Before providing business skills, strengthening financial capital and or developing economically productive street vendors, first APM is carried out on street vendors who need special attention, and are deemed necessary to be assisted in continuing their business. APM approach includes Problem Background Analysis; Fact Problem Analysis; Problem Impact Analysis; Meta Problem Analysis; Philosophy Analysis of the Problem; and Problem Solution Analysis to determine the appropriate economic empowerment model for each street vendor. PKL economic empowerment is carried out in order to increase the legality, capacity and professionalism of street vendors in managing businesses, and is directed to be able to become formal entrepreneurs.

4. Proposition: From the description of the new concept, the following propositions can be drawn: Environmental control, social services and economic empowerment of street vendors as business actors in the community economic system determine the effectiveness of Sat Pol PP in enforcing local regulations.

\section{CONCLUSION}

To answer research questions and achievements through discussion of interview results, according to the research design, the following conclusions can be stated:

1. Enforcement of Regional Regulations No. 2 of 2020 against street vendors in the West Jakarta Administrative City by Satpol PP has not been effective in realizing humanist normative pattern of enforcement. The enforcement performance with a humanist normative pattern is the implementation of regulation on controlling the street vendors, which is carried out with a friendly approach, does not commit violence and confiscation of goods and shows the existence of a social service cooperation 
and economic empowerment of street vendors.

2. With the organizational effectiveness analysis approach from Tyson \& Jackson, it can be revealed the performance of street vendors control as follows:

a. The implementation of operational directives is faced with conditional and situational constraints related to the human side, so that the Sat Pol PP members tend to find it difficult to optimally enforce Regional Regulations against street vendors;

b. b. The delegation of authority for Sat Pol PP according to the organizational structure from the Provincial level to the Kelurahan level is not only highly hierarchical but also highly procedural so that it hinders the implementation of Satpol PP's public service functions;

c. c. The operational control of Sat Pol PP in carrying out control of street vendors is faced with weak implementation of coordination functions in the field.

d. d. The operational responsibility of Sat Pol PP in implementing policies and activities to control street vendors is limited to the scope of accountability for the structural performance of the bureaucracy, not yet on social accountability and political accountability.

e. e. The operational efficiency of Sat Pol PP in enforcing regional regulations has not maximized the function of budget allocation. The efficiency parameter in the performance of PKL control has not changed into a parameter of the effectiveness of achieving goals and objectives.

f. f. The operational coordination of Sat Pol PP is mostly carried out to meet the technical operational needs within Sat Pol PP and with related agencies / institutions. However, the implementation of the coordination function to meet social needs is at the heart of PKL problems.

g. g. The operational technical adaptation has been carried out by Sat Pol PP but has not been optimal in anticipating efforts to fulfill the demands of formal legality and the challenges of realizing Jakarta a Social Friendly City and Social Justice.

h. h. The Social System and Individual Expectations that formally appear in the implementation of various policies and control activities for the Sat Pol PP are still limited to the social system and individual expectations within the Sat Pol PP internal environment. The social system and individual expectations in the broadest sense, especially those related to street vendors have not been actualized.

3. During the Covid 19 pandemic, the enforcement of a humanist normative pattern must be adjusted to the conditions that occur. For this reason, the ideal concept that needs to be developed as an effective model in enforcing local regulations against street vendors during the Covid-19 pandemic is through a policy to control street vendors with a Humanist Normative pattern with a conceptual definition: The Humanist Normative Patterned Street Vendor Control Policy is performance management. control of street vendors by controlling the environment, social services and economic empowerment of street vendors as business actors in the community economic system, which is carried out in the context of realizing a Social Friendly City and Social Justice. This definition includes three approaches: (1) Environmental Stewardship; (2) Social Services; and (3) Economic Empowerment.

4. Referring to the description above, the authors need to provide policy 
recommendations for the results of the research as follows:

a. Enforce the implementation of street vendor control regulations in DKI Jakarta with a friendly approach, non-violence and confiscation of goods to support the realization of Jakarta, a Social Friendly City during the Covid 19 Pandemic

b. Implement a more practical and decentralized pattern of delegation of authority so that the Sat Pol PP in each Administrative Regency / City can carry out public service functions optimally to support the realization of conducive social welfare conditions during the Covid 19 pandemic

c. Implementing more conceptional operational control of street vendors by developing functional cooperation between Sat Pol PP and agencies and institutions that are concerned with social services and economic empowerment of street vendors.

d. Extending the operational accountability for controlling street vendors by Sat Pol PP by enforcing public accountability in accordance with the principles of good governance.

e. Improve the operational efficiency of controlling street vendors by Sat Pol PP by maximizing the amount of budget allocations so that the implementation of various policies and activities to control street vendors is effective.

f. Expanding the operational coordination of PKL control carried out by Sat Pol PP to reach all parties with an interest in the presence of street vendors as one of the informal business actors who have a certain potential and position in the economic system of the Jakarta community g. Expanding the operational technical adaptation of PKL control carried out by Sat Pol PP in addressing, overcoming and anticipating all dimensions of PKL problems to support the realization of Jakarta, a Social Friendly City and Social Justice.

h. Developing a social system and individual expectations that formally arise through the operational activities of the Sat Pol PP in enforcing local regulations to support the realization of Jakarta, a Social Friendly City and Social Justice.

\section{REFERENCE}

2002, Pengantar Studi Ilmu Administrasi dan Manajemen, Jakarta : Haji Masagung

Ashraf, 2012. A Review on the Models of Organizational Effectiveness: A Look at Cameron's Model in Higher Education, Journal International Education Studies Vol. 5, No. 2.

Cheema, G Shabbir \& Rondinelli, Dennis A, 1983, "Decentralization and Development", Sage Publication, Inc

Chen, M. COVID-19, 2020,Cities and Urban Informal Workers: India in Comparative Perspective. Ind. J. Labour Econ. 63, 41-46 (2020)

Christensen T., Lægreid P., Roness P.G.2007. Organization Theory and the Public Sector: Instrument, Culture and Myth. Routledge, London and USA.

Gedeian, Arthur G. 1991. Organization Theory and Design. University of Colorado at Denver.

Gibson, James L, John M. 1996. Organizations: Behaviour, Structure and Process, McGraw-Hill Companies Inc, Boston.

Gibson, James L, John M. Ivancevich dan James H. Donnelly Jr, 1989. Organisasi. Edisi Kelima. Jakarta: PT. Gelora Aksara Pratama.

Gunarto, Jamil dan Jawade Hafidz, 2019. Reformation On The Role And 
Responsibilities Of The Pamong Praja Police In The Enforcement of Regional Rule Of Batam City Number 16 Of 2007 Concerning General-Based Provisions And Regulations, International Journal of Law, Volume 5; Issue 6.

Handayaningrat, Soewarno, 1989, Administrasi Pemerintahan Dalam Pembangunan Nasional, Jakarta : CV. Haji Mas Agung.

Hesselbein, Goldsmith, Beckhard. 1997. The Organization of the. Future, San Fransisco : Jossey Bush Publisher

Honey-Roses, Jordi, Isabelle Anguelovski, Josep Bohigas, Vincent K. Chireh, Mr., Carolyn Daher, Cecil Konijnendijk, Jill Litt, et al. 2020. The Impact of COVID19 on Public Space: A Review of the Emerging Questions. OSF Preprints. April 21.

Kumar, Arvind, 2001, Encyclopaedia of Decentralised Planning and Local SelfGovernance, Volume 1,. Anmol Publications PVT.LTD : New Dehli.

Kurniawan Kurniawan, Agung. 2005. Transformasi Pelayanan Publik. Yogyakarta: Pembauran.

LAN RI, 1997, Sistem Adminstrasi Negara Kesatuan Republik Indonesia, Jakarta: Lembaga Administrasi Negara Republik Indonesia.

Lubis, Hari. S.B. dan Martani Husaini. 1987. Teori Organisasi (Suatu Pendekatan Makro), Pusat Antar Universitas Ilmuilmu Sosial Universitas Indonesia, Jakarta.

McCann, J. 2004. Organizational effectiveness: Changing concepts for changing environments. Human Resource Planning, 27(1).

Miftah Thoha. 2004. Perilaku Organisasi, Konsep Dasar dan Aplikasinya. Jakarta: Raja Grafindo Persada

Nanik Setyowati, Martinus Legowo, FX Sri Sadewo, Katon Galih Setyawan, 2016. Public View Towards Civil Service Police Role Shifting in the Society Order and Security in East Java, Journal Research on Humanities and Social Sciences, Vol.6, No.14.
Rahmawati, Haerani, S., Taba, M., \& Hamid, 2016. Measures of Organizational Effectiveness: Public Sector Performance, IRA-International Journal of Management \& Social Sciences, 5(2).

Rasyid Thaha, 2016. Public Ethics in Civil Service Police Unit (Satpol PP) of Makassar, International Journal of Administrative Science \& Organization, Vol 23, No 1, .

Robbins, Stephen P, 2002. Teori Organisasi: Struktur, Desain dan Aplikasi. Jakarta: Arcan.

Shangcong Song, 2020, "Street stall economy in China in the post-COVID-19 era: Dilemmas and regulatory suggestions", dalam Research in Globalization, Volume 2, 2020, Elsevier

Steers, Richard M, 1985, Efektivitas Organisasi, (Alih Bahasa : Magdalena Jamin), Edisi Kedua , Jakarta : Penerbit Erlangga.

Tyson Shaun \& Tony Jackson, 2000, The Essense of Organizational Behavior, Cetakan Pertama. Jogjakarta:ANDI 